No one, including myself, is a permanent fixture on this Journal since it exists for the entire membership of the College Theology Society. So there will be more changes over the next two or three years. It is important that we welcome fresh and invigorating perspectives while we take care to ensure the continued quality and growth of Horizons.

-BERNARD P. PRUSAK

\title{
ON CELEBRATING NEWMAN'S FAITH IN THE LAITY
}

(A guest editorial from a member of the College Theology Society teaching at the University of Dayton.)

This year marks the centennial of John Henry Newman's elevation to Cardinal on May 12, 1879, which was the result of a request of England's Catholic laity as voiced by the Duke of Norfolk. Some reflections seem appropriate.

A number of sources give great credence to John Coulson's edition of Newman's On Consulting the Faithful in Matters of Doctrine (New York: Sheed \& Ward, 1961). Coulson's Introduction describes Newman's great concern for Catholic education. It is surprising that the Catholic Bishops of England did not share this fervor and resented these democratic tendencies. Bishop Ullathorne of Birmingham wrote to one proponent, Simpson, that the bishops found it "absolutely unnecessary that the reasons for our own actions should be explained and that the Catholic community should be informed of the grounds of our proceedings" (Coulson, p. 16).

In the heat of this debate Newman became the editor of Rambler, a Catholic journal which published articles somewhat critical of England's Rome-oriented conservative hierarchy. In his first edition, May 1859, Newman wrote in favor of people like Simpson. He addressed the bishops on the issue of community involvement.

we do unfeignedly believe ... that their Lordships really desire to know the opinion of the laity on subjects in which the laity are especially concerned. If even in the preparation of a dogmatic definition the faithful are consulted, as lately in the instance of the Immaculate Conception, it is at least as natural to anticipate such an act of kind feeling and sympathy in great practical questions (Coulson, p. 8).

Bishop Ullathorne became antagonized by Newman's editorial, and pressured him to give up his new position. The July 1859 issue of 
Rambler was Newman's last edition and there he published his now famous "On Consulting the Faithful in Matters of Doctrine." Newman emphasized a concept essential to his conversion to Catholicism. In his historical studies of Christianity Newman discovered that the Catholic faith proved itself so sound and strong that it could withstand the corrosion of heresies which emerged on its way. This soundness of faith is expressed by the Greek word, phronema, and it is at the core of Newman's ecclesiology.

Speaking to the Catholic hierarchy Newman intended to share his dramatic discovery of this phronema in the long battles of the Catholic faith against the Arian heretics. Newman found, and this is the foundation of his argument, that in those days the laity, and not the hierarchy, was the true defender of the Catholic faith. Even Pope Liberius caved in under the Arian pressure and "confirmed the sentence passed against Athanasius" (Coulson, p. 82).

After enumerating many instances where the hierarchy showed Arian affiliations, Newman delighted in listing those occasions where the laity defended with great fervor the true Catholic position as formulated at the Ecumenical Council of Nicaea in 325. All this led to his conclusion:

I think certainly that the Ecclesia docens (the teaching Church) is more happy when she has such enthusiastic partisans about her as are here represented, than when she cuts off the faithful from the study of her divine doctrines and the sympathy of her divine comtemplations, and requires from them a fides implicita (an uneducated faith) in her word, which in the educated classes will terminate in indifference, and in the poorer in superstition.

Yes, it is remarkable that Newman found opponents among the Catholic hierarchy and had to fight for education. This sounds unbelievable in our day of prolific adult education programs, sound Catholic school systems, and an impressive flood of books on religious and Christian education. Because of the opposition, Newman felt called to produce this remarkable document, which is now a gem in the history of Catholic evolution.

Rumor regards Newman as one of the spiritual Fathers of Vatican II. Implied in such honorable distinction is that Newman's theology has made two tremendous contributions to the growth of Catholic thought. One is his very perceptive book on the development of Christian doctrine, which he finished just before his public conversion to Catholicism. The number two contribution is surely his personal affirmation of the sound faith situated within the people of the Church. Although he perceived the Church as one Mystical Body of Christ, Newman gave special recognition to the laity which had proven in history to be resilient in the defense of the true faith. I would like to raise the question, "Is 
this aspect of phronēma properly delineated in the documents of Vatican II?"

Vatican II really wants to express a deep appreciation for the laity. However, the role of the laity is very much relegated to the realm of the secular life where business, industry, technology and science give muscle to modern civilization and the building of the Kingdom. The role of the laity is to be good Christians on those frontiers. With the possible exception of the first paragraph of section 10 of the Constitution on Revelation, there is no explicit emphasis on the laity's importance for the maintenance of the Catholic faith. That role is assigned to the ecclesia docens which is another word for the Church's hierarchy.

It would seem that Newman's theology did not really become explicit in the Vatican II documents. Rather, according to Samuel D. Femiano in his Infallibility of the Laity (New York: Herder and Herder, 1967), his thought colored a mentality which surfaced in discussions about certain formulations. For example, in the debate on the laity and the hierarchy one subcommission mentioned that the sensus fidei (supernatural discernment) "was not being considered in the text as a particular prerogative of the hierarchy but as a power of the whole Church" (p. 135). Femiano sees this as "the Council's desire to mark the unity of the faithful with the bishops as participants in the one prophetic office of Christ" (p. 136). Moreover, Femiano refers to discussions about the relation between the teaching authority and the infallibility (sic) of the faithful. In this respect he writes:

From an investigation of the Church's tradition, it was found that the process of the development of doctrine sometimes begins in the people; their consensus activates the infallible teaching authority of the magisterium. In such cases the faithful's infallibility is not merely a passive reflection of the magisterium's teaching but it is an active exercise of the laity's prerogatives (p. 136).

It seems that the next Ecumenical Council has the task of giving greater significance to the infallibility of faith situated within the laity of the Church. A deeper development of Newman's understanding of phronema would benefit the Catholic people. Those scholars who convened in 1977 for an exchange of ideas toward Vatican III voiced this concern. However, the idea of phronema should be conceived not so much as a static resource of Catholic truth but rather that the Catholic people will develop greater understanding of their faith in their historical struggles for social justice, liberty, and human love.

Newman connected the faith of the laity with the concept, ecclesia docta meaning that the laity is taught by the teaching Church, ecclesia docens, and thus becomes the receptacle of the Christian doctrine. The role of the laity in these matters is still rather passive. For that reason it 
seems fortuitous that Vatican II assigned the laity a somewhat "secondary" role - to be good Christians in the secular realm. We must understand that this secular realm constitutes the frontier where the Christian faith will be tested. It is the realm where the Christian faith will receive new understanding in the light of new challenges and new opportunities. Within such perspectives, it seems that the ecclesia docens, as the authority which is called to preserve the traditional truth of its doctrine, becomes more and more passive. One comes to expect creativity, newness, and vitality to be provided by the laity who as the living blood and breath of the Church respond to the secular realm assigned to them. Somehow, this seems to be more and more the case in those countries where the laity have taken their responsibility seriously and are now challenging the hierarchy to catch up with development and growth.

Upon reading Coulson's account of Newman's brief period as editor of Rambler one is dismayed by the incredible hardness of heart he encountered on the part of the English Catholic hierarchy. So often in history the great spirituality of outstanding Christians finds major opposition from within their Church. Great women and men, of course, transcend this resistance. But we should try to appreciate all the suffering inflicted on such a man as Newman. Happy for him, he found great recognition and vindication in his elevation to Cardinal. But that does not happen often. Such a good ending seems possible only in Hollywood movies, which are lately reluctant to produce happy endings. The great Pierre Teilhard De Chardin never saw the day when his thoughts were celebrated by Catholic theology. Sadly he died rather lonely under the shadow of the Church's disapproval.

The memorial of Newman's elevation to Cardinal should be a celebration of justice having found a way to liberate a victim from prejudice, rejection, and suspicion.

-WILLIAM P. FROST

\section{MUSIC OF THE SPHERES}

It was a lazy day in April when we arrived at the office, perfunctorily raised the lid of our old roll-top desk, and began shuffling through the morning's mail. A glossy brochure caught our eye. "Yoga Ranch, in pastoral Prairie Dog Village, South Dakota. A quiet place away from the distractions of our gimmick-ridden society, our fast food counters; far, far away from the numbing sounds of electronic gadgetry and the din of the gasoline combustion engine. Yoga Ranch offers seminars on

The Metaphysics of Digestion

Aquarian Divination 